\title{
Specifics of hydro-loosening of coal seams with account of rocks displacement parameters
}

\author{
Vasyl Zberovskyi ${ }^{1 *}$, Olena Bubnova ${ }^{1}$, and Kateryna Babii ${ }^{1}$ \\ ${ }^{1}$ Institute of Geotechnical Mechanics under the National Academy of Science of Ukraine, \\ 2a Simferopolska St., 49005 Dnipro, Ukraine
}

\begin{abstract}
The analysis of efficiency decline of methods for hydraulic influence on outburst-prone coal seams in the conditions of large depths is represented. The models are considered for parameters calculation of highpressure liquid injection, based on the hypotheses of the stress-strain state formation of the coal seam; the patterns of rock pressure manifestation as well as calculation discrepancy between the liquid injection pressure and the terms of large depths, are established. It is shown that in the parameters calculation of the high-pressure liquid injection, it is necessary to take the height of the column of rocks which lost their integrity and form the stratification zone in the underworked massif instead of depth $H$ of the seam mining. It has been established that the efficiency of hydro-loosening depends not only on the injection pressure, but also on the location of borehole filtration part relative to the maximum of abutment zone.
\end{abstract}

\section{Introduction}

The most widespread and simple in technological performance, the method of gas dynamic phenomena (GDP) prevention is hydro-loosening of the coal seam selvedge in the mode of static liquid injection in the Donetsk Basin mines. The method is based on high-pressure injection and on the research results conducted in Makiivskyi naukovo-doslidnyi instytut (MakNDI) on the safety of works in the mining industry more than 60 years ago, when the mining operations were carried out at depths from 400 to $700 \mathrm{~m}$.

With the deepening of mining operations, the technological schemes of the methods were revised, and the injection parameters remained unchanged [1-4]. In a normative technique for parameters calculation of hydro-loosening [3], the injection pressure of a liquid is determined by the formula:

$$
P_{f}=(0.75-1.0) \gamma H
$$

where $\gamma$ is the specific gravity of rocks; $H$ is the depth of mining of the coal seam.

By the empirical coefficient $(0.75-1.0)$, it has been determined the injection pressure range in the static mode, in which the unloading zone and the pack-off depth are determined experimentally. The parameter $\gamma H$ characterizes the rock pressure, which is created by the column of rocks, whose height is equal to the depth $H$ of mining, according

\footnotetext{
* Corresponding author: avalansh@ua.fm
} 
to hypothesis of O.M. Dynnyk.

Nowadays, there are quite enough theories and experimental data confirming the change in the molecular structure of coal under the influence of technogenic factors arising in the geological stratum. The shearing strains lead to structural coal changes with the formation of supermelonits and to generation of methane by the coal substance [5-7]. However, these processes are not considered in methods for calculation of a selvedge condition of an outburst-prone seam.

Therefore, in the conditions of large depths, despite the application of measures, the gas dynamic phenomena are still occurring with catastrophic consequences [2]. On the one hand, accidents arise because of a human factor, and on the other one, because of the insufficient study of the processes arising in a selvedge of the mined outburst-prone seam.

\section{The results of calculating the pressure of the liquid injected into the coal seam}

Let us consider the research results of mining-and-experimental operations of hydro-pulse impact on the example of hydro-loosening of $i_{3}^{1}$ seam of horizon $915 \mathrm{~m}$ in the conditions of JV "Sukhodolske-Skhidne", at depth of the seam mining $H \geq 1100 \mathrm{~m}, \gamma=2.65 \mathrm{t} / \mathrm{cu}$. m.

According to (1), the range of liquid injection pressure should be equal to $22-29 \mathrm{MPa}$, and pack-off depth not less than the size of unloading zone. Whereas, the unloading zone and the safe depth of coal mining by the shearer depend on the type of support setting in mine working and the rate of its drivage. Thus, it has been established that at setting of the frame support and the rate of mine working drivage from 2 to $4 \mathrm{~m}$ per day, the unloading zone is equal from 5 to $3.5 \mathrm{~m}$, respectively. When frame-and-roof bolting and roof-bolting, the size of the unloading zone is stabilized and is equal to $3.5-4.0 \mathrm{~m}$. The given results of research show that the pack-off depth accepted based on experimental injections $l_{p}=4.0 \mathrm{~m}$ at a borehole length of $l=6.0 \mathrm{~m}$, does not always correspond to the mining conditions.

The long-term MakNDI observations have established that in the case of hydroloosening, the break of seam tightness or sloughing of one of its splits occurs at an injection pressure in the range of $20-30 \mathrm{MPa}$. The similar results have been obtained also in our example. Thus, during pack-off at a depth of $4 \mathrm{~m}$ and injection pressure of more than $25 \mathrm{MPa}$, the breakthrough of the liquid into mine working face happened in $4-5$ min after injection.

The above mentioned allows to draw a conclusion that the normative technique for calculation of hydro-loosening parameters [3] does not correspond to conditions of large depths. It should also be noted that when calculating the injection pressure (1), an important pack-off depth parameter is not considered.

Therefore, the objective of the work is to analyze the research results of calculated and set in practice values of the static and pulse modes parameters of liquid injection with account of patterns of rocks displacement in the conditions of large depths.

It is well known that filtration properties of coal in selvedge of a seam are considerably influenced by the rock pressure value and stress state of the coal massif. Between water permeability of coal and rock pressure there is a distinct feedback - with increase in pressure the water permeability of a seam decreases and vice versa, as the rock pressure decreases, the water permeability increases.

The results analysis of practical application of GDP prevention methods based on highpressure liquid injection in the Donbas mines makes it possible to note the following.

The decrease in coal permeability in the abutment zone is effectively used in the hydraulic sloughing of the selvedge of a seam. The technological parameters of the blasthole [3] allow to locate its filtration part in the zone of abutment pressure maximum, and to 
regulate the additional loading force on the selvedge of a seam by liquid injecting under pressure of $P_{f} \geq 0.75 \gamma H$. However, this process is connected with high probability of GDP initiation and is carried out remotely without the presence of people in mine working throughout all its length. If it does not cause difficulties in a stoping face, but in the preparatory mine working it leads to a decrease in the rate of its drivage by more than $50 \%$.

The method of hydro-loosening also has its own features. So the location of the filtration part of the borehole, the length of which is $2.0 \mathrm{~m}$ relative to the abutment zone maximum, is of great technological importance. If, even its insignificant part is located in the unloaded zone, then in the process of injection there happens the breakthrough of liquid into the mine working face. If the filtration part of the borehole is located in the zone with an increased rock pressure or behind it, then because of low water permeability of the coal and, as a rule, the existence of carbonaceous inter-layers, natural pockets and cracks in the seam, the liquid breakthrough occurs in the unknown direction.

As we can see, the efficiency of static liquid injection depends on the location of the filtration part of the borehole relative to the boundary of the abutment zone. Nowadays, this problem is solved by control of unloading zone with a probable error of $0.5 \mathrm{~m}$. It corresponds to the interval of drilled check blast-holes in determining the pack-off depth. The second task - to control the liquid filtration process in the coal seam at static injection - has not been solved yet due to the lack of control methods.

Thus, the application of methods with the mode of static liquid injection in conditions of large depths not only does not ensure the safety of works, but also becomes a constraint factor.

At the same time, the mining-and-experimental works on the hydro-pulse effect on the outburst-prone coal seams have shown that the application of pulse injection modes allows to solve this problem. However, the parameters of this method with account of the stressstrain state formation of the selvedge of a seam have not been sufficiently studied yet.

It is known that during mining operations in underworked massif there is a collapse of rocks with a constant main roof spacing. In the conditions of large depths, this leads to the formation of zones of compression, tension and stratifications (Fig. 1) [8-11].
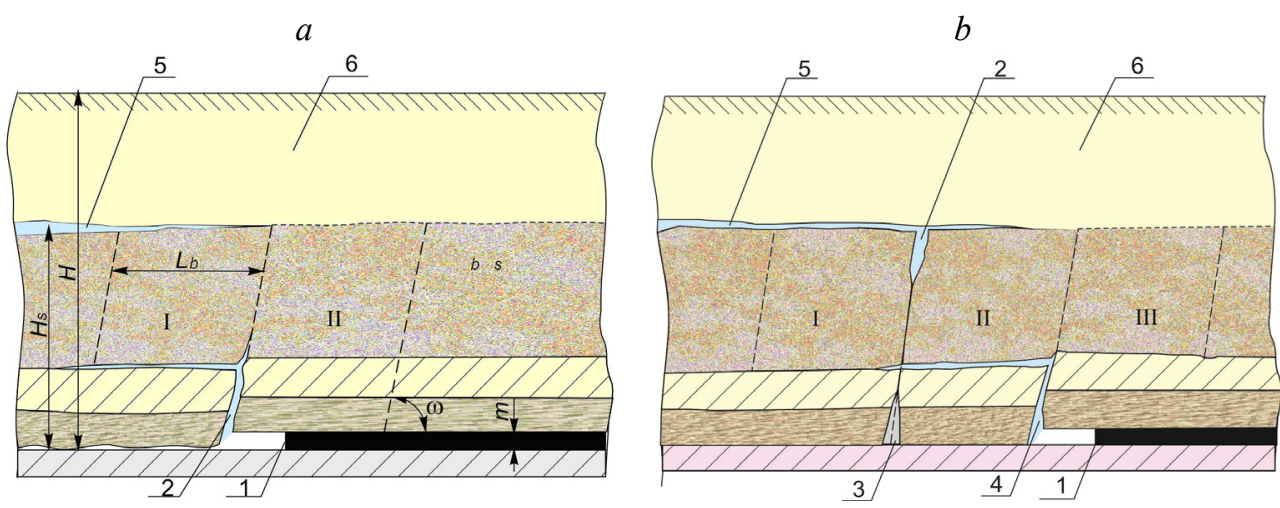

Fig. 1. The scheme of tension, compression and stratifications zones formation during rocks breakage at large depths: a - during collapse of the main roof block I; b - formation of stratification and compression zones [9]: 1 - stoping face; 2 - tension zone; 3 - compression zone; 4 - tension zones between blocks; 5 - stratifications zone; 6 - deformation zone of rocks without their discontinuity.

In the geological strata of the coal seams suite, the displacement of rocks initiates the technogenic transformations that exert an impact on the whole massif of the mine field. The structural transformations of coal with phase transitions of coal-gas occur in the outburstprone seams. In tension zones, there is a possibility of free methane filtration that leads to 
degassing of the massif and formation of the unloaded safe zone. The compression zones on the contrary become the high rock pressure zones (HRPZ) in which the transformed outburst-prone coal seams acquire the stress-strain state with a high probability of selfdestruction.

The generally accepted hypothesis of the stress-strain state formation of a coal seam is the model of Dynnyk O.M.:

$$
\sigma_{y}=\gamma H
$$

It is accepted in the model that the pressure is created by the rocks massif, whose column height is equal to the depth $H$ of mining. The research of authors $[8,9]$ substantiated that in the expression (2) the conditions of large depths are not considered when the stratification zone is formed in the underworked massif. At a certain point of time, namely in the period of formation of tension and compression zones in the underworked massif, rock pressure has a value equal to:

$$
\sigma_{m}=\gamma H_{x}
$$

where $H_{x}$ is the height of the column of rocks, which at the moment have lost the integrity with the massif, $\mathrm{m}$.

The height of the column and the rock pressure value can be determined by calculating the rate of deformations development in the massif according to the results of minesurveying observations of displacement process development. In the work [9] it is shown that in the conditions of large depths, when calculating the rock pressure value, only that part of rocks should be considered which has been separated from the underworked massif because of displacement. Based on the long-term research and experience of surveying observation, the height of this column at depths more than $1000 \mathrm{~m}$, depending on the rocks lithification degree, ranges from 600 to $800 \mathrm{~m}$.

With account of the defined features of rock pressure manifestation, we will consider how the parameters of liquid injection into coal seam will change. For this purpose, we will use the model for calculating the liquid injection pressure under static and pulse injection modes (Fig. 2) [12, 13].

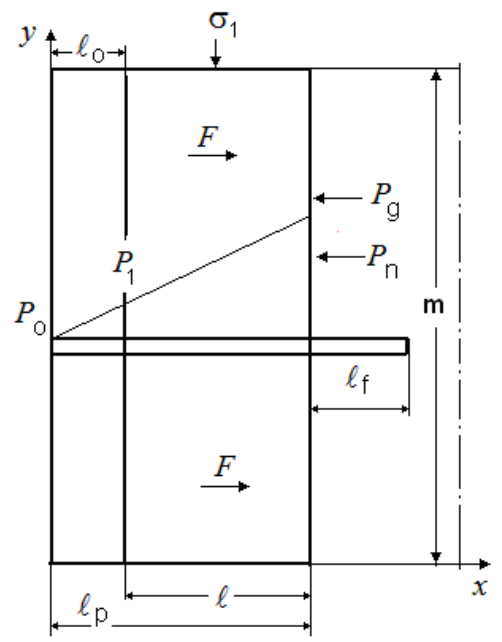

$\sigma_{1}-$ rock pressure forces, $\mathrm{MPa}$;

$\sigma_{1}=\gamma H ; \gamma \approx 2.65$ t/cu.m;

$P_{\mathrm{n}}-$ injection pressure, $\mathrm{MPa}$;

$P_{\mathrm{g}}-$ gas pressure in seam, $\mathrm{MPa}$;

$P_{\mathrm{g}}=1.0-2.0 \mathrm{MPa}$;

$F$ - friction forces, $\mathrm{MPa} ; F=f \sigma_{1}=f \gamma H$;

$f$ - friction coefficient of rocks,

in massif $f=0.5$;

$P_{0}$ - liquid pressure on the surface of mine

working face, $P_{0}=0$;

$P_{1}-$ liquid pressure on a seam edge, $\mathrm{MPa}$;

$m$ - seam thickness, $\mathrm{m}$;

$l_{\mathrm{p}}$ - pack-off depth, $\mathrm{m}$;

$l_{0}$ - destroyed seam edge, $\mathrm{m} l_{0}=0.1 \mathrm{~m}$;

$l_{f}$ - depth of filtration chamber, $\mathrm{m}$;

$l$-depth of seam resistance zone, $\mathrm{m}$.

Fig. 2. The scheme for calculating the pressure of liquid injection into coal seam with account of hydraulic sloughing and pack-off depth criteria. 
In our example, the calculation parameters of hydro-loosening are as follows: depth of occurrence $H=1100 \mathrm{~m}$; specific gravity of rocks $\gamma=2.65 \mathrm{t} / \mathrm{cu} . \mathrm{m}$; seam thickness $m=1.75 \mathrm{~m}$; depth of the borehole drilling $-6.0-8.0 \mathrm{~m}$; pack-off depth $l_{g}=2.5-5.5 \mathrm{~m}$; friction coefficient of rocks in the massif $f=0.5$; height of the column of rocks, which have lost their integrity with the massif $H_{x}=600 \mathrm{~m}$.

Consider the results of calculating the hydro-loosening parameters of coal seams according to the normative technique [3] in the static mode of liquid injection. As it was noted earlier, the calculated range of liquid injection pressure by the formula (1) is equal to $22-29 \mathrm{MPa}$. At the same time, the change of technological parameters is considered by the empirical coefficient in the range of $0.75-1.0$.

It has been established that when hydro-loosening through boreholes with $6.0 \mathrm{~m}$ length and $4.0 \mathrm{~m}$ pack-off depth, with an injection pressure of $23 \mathrm{MPa}$ and more, a breakthrough of liquid and a pressure drop occurred in $10-15$ minutes. The hydro-loosening without a breakthrough of liquid into mine working occurred at a pressure of no more than $22 \mathrm{MPa}$, which is less than the range established by the formula (1).

These results have confirmed once again that the problem of hydraulic fracturing and hydraulic sloughing during hydro-loosening, has been neither theoretically, nor practically solved.

At the same time, based on the analysis of the numerous experimental data obtained in the process of hydro-loosening in the conditions of large depths, the calculated pressure of the hydraulic sloughing $P_{n} \geq 0.75 \gamma H$ [3] always corresponds to boundary value of the liquid injection pressure. Moreover, the efficiency of hydro-loosening depends on the location of the rock pressure maximum ahead of the mine working face and on the pack-off depth. Then, based on the condition of forces equilibrium on the contacting surfaces "seam - enclosing rocks" (Fig. 2), the phenomenon of hydraulic sloughing at the pack-off depth will occur at $P_{1}=0[12,13]$ :

$$
\left(P_{n}-P_{1}\right) m=2 f \gamma H\left(l_{p}-l_{0}\right) .
$$

It follows from the condition (4) that if in the process of liquid injection into the coal seam the stress-strain state of the massif and the energy of the gas accumulated in the seam exceed the contact friction forces, in the coal seam there will necessarily occur the hydraulic sloughing and hydraulic fracturing of interlayers composing the coal seam.

Then, according to the model (Fig. 2), the condition of hydraulic sloughing at the accepted depth of pack-off will be written as follows:

$$
P_{n} \geq \frac{2 \cdot f \cdot \gamma \cdot H}{m} \cdot l_{p}=\frac{2 \cdot 0.5 \cdot 2.65 \cdot 1100}{1.75} \cdot l_{p}=16.65 \cdot l_{p},
$$

and with account of condition of rocks stratification, at height $H_{X}(3)$ :

$$
P_{n} \geq \frac{2 \cdot f \cdot \gamma \cdot H_{X}}{m} \cdot l_{p}=\frac{2 \cdot 0.5 \cdot 2.65 \cdot 600}{1.75 \cdot l_{p}}=9.08 \cdot l_{p} .
$$

By these formulas, depending on the pack-off depth, the calculation of injection pressure (Table 1) is made.

Consider the received calculation results with respect to the results established in practice.

When hydraulic sloughing the selvedge of a seam, the pack-off depth of the blast-hole should be from 2.0 to $5.5 \mathrm{~m}$, and its filtration part $0.3 \mathrm{~m}$ [3]. In practice, the blast-holes from 2.5 to $3.5 \mathrm{~m}$ length are commonly used. With these parameters, the self-destruction of the seam is most effectively realized in the abutment zone in terms of the technology of 
hydraulic sloughing.

From the table, when calculating by the formula (5) the injection pressure from 41.6 to $58.3 \mathrm{MPa}$, and by the formula (6) from 22.7 to $32 \mathrm{MPa}$, corresponds to these parameters. According to the long-term MakNDI observations [1, 2], at depths more than $1000 \mathrm{~m}$ the hydraulic sloughing occurs at an injection pressure in the range of $20-30 \mathrm{MPa}$. These values coincide with the results calculated by the formula (6).

Table 1. Calculated values of hydraulic sloughing pressure of the selvedge of a seam depending on the pack-off depth and stratification zone of rocks.

\begin{tabular}{|c|c|c|c|}
\hline \multicolumn{2}{|c|}{ According to the formula (5) } & \multicolumn{2}{c|}{ According to the formula (6) } \\
\hline$L_{g}, \mathrm{~m}$ & $P_{n}, \mathrm{MPa}$ & $L_{g}, \mathrm{~m}$ & $P_{n}, \mathrm{MPa}$ \\
\hline 2.5 & 41.6 & 2.5 & 22.7 \\
\hline 3.0 & 49.9 & 3.0 & 27.2 \\
\hline 3.5 & 58.3 & 3.5 & 31.8 \\
\hline 4.0 & 66.6 & 4.0 & 39.2 \\
\hline 4.5 & 66.4 & 4.5 & 40.9 \\
\hline 5.0 & 83.2 & 5.0 & 45.4 \\
\hline 5.5 & 91.6 & 5.5 & 53.9 \\
\hline
\end{tabular}

Now let us compare the calculated data with the results of hydro-loosening of $i_{3}^{1}$ seam of horizon $915 \mathrm{~m}$ in JV "Sukhodolske-Skhidne" of PJSC "Krasnodonvuhillia" [14]. With a pack-off depth of the technological borehole of $4.0 \mathrm{~m}$, according to the unloading zone size from 3.5 to $4 \mathrm{~m}$, its filtration part of $2.0 \mathrm{~m}$ was located behind the abutment zone maximum. The breakthroughs of liquid into the mine workings face were fixed at an injection pressure of more than $23 \mathrm{MPa}$. At an injection pressure of more than $25 \mathrm{MPa}$, the hydraulic fracturing of the seam and drop in injection pressure occurred in $4-5$ minutes, and the signs of hydraulic sloughing in the mine working face were not observed.

In accordance with the set values at these parameters of technological boreholes (Table 1), according to the normative technique (5) of calculation, the hydraulic fracturing (hydraulic sloughing) can occur at an injection pressure of more than $66 \mathrm{MPa}$, and when calculating by formula (6) at a pressure of $39 \mathrm{MPa}$. As we can see, the results of calculation of liquid injection pressure by the formula (5) almost three times exceed the values set in practice. The results obtained by the formula (6) most closely correspond to them.

The importance of conducted research is that by comparing the calculation results and experimental data, the discrepancy of calculation model of liquid injection pressure is determined, based on the hypothesis of stress-strain state formation of coal seam under the pressure, which is created by the height of rocks column equal to the depth $H$ of mining.

\section{Conclusions}

Comparison of the calculation results of the pressure of liquid injected into the coal seams with the results established during the work has shown that in the conditions of large depths the generally accepted hypothesis of the stress-strain state formation of a coal seam under pressure which is created by the height of a column equal to the depth $H$ of mining, does not correspond to practical results.

It has been shown that when calculating the parameters of high-pressure liquid injection, it is necessary to take the height of the column of rocks which lost their integrity and form the stratification zone in the underworked massif instead of depth $H$ of the seam mining. 
For the first time in the practice of hydro-loosening of coal seams, the calculations have been made for determination of liquid injection pressure depending on pack-off depth with account of rocks displacement features at large depths.

The authors of the article express their gratitude to the engineers of PJSC "Krasnodonvuhillia" mines for the assistance in conducting mining and experimental research.

\section{References}

1. Timofeev, E.I., Mhatvari, T.Ya., Churadze, M.V., \& Ryzhkov, M.F. (2003). Metodika vybora optimal'nykh parametrov gidrorykhleniya vybrosoopasnykh ugol'nykh plastov. Sbornik nauchnykh trudov Makeyevskogo Nauchno-Issledovatel'skogo Instituta, (1), 81-90.

2. Boyko, Ya.N., Nikiforov, A.V., \& Rubinskiy, A.A. (2009). Povyshenie effektivnosti gidrorykhleniya vybrosoopasnykh ugol'nykh plastov v podgotovitelnykh vyrabotkakh i nishakh. Sbornik nauchnykh trudov Makeevskogo Nauchno-Issledovatel'skogo Instituta, 2(24), 52-57.

3. SOU 10.1.001740088.011:2005. (2005). Pravyla vedennia hirnychykh robit na plastakh, skhylnykh do hazodynamichnykh yavyshch. Kyiv: Ministerstvo vuhilnoi promyslovosti Ukrainy.

4. Zberovskiy, V.V., \& Androshchuk, K.V. (2002). O degazatsii i sdvizhenii geologicheskoy tolshchi pri osvoenii mestorozhdeniy na bol'shikh glubinakh. Gornyy informatsionnoanaliticheskiy biulleten' Moskovskogo Gosudarstvennogo Gornogo Universiteta, (6), 70-72.

5. Zberovskiy, V.V. (2004). K voprosu transformatsii tverdykh uglevodorodov i sistemy "ugol' gaz”. Gornyy informatsionno-analiticheskiy biulleten' Moskovskogo Gosudarstvennogo Gornogo Universiteta, (8), 188-192.

6. Sobolev, V.V., Polyashov, A.S., Zberovskiy, V.V., Angelovskiy, A.A., \& Chugunkov, I.F. (2013). Sistema “ugo'l-gaz" v uglevodorodakh ugol'nogo genezisa. Dnepropetrovsk: Art-Press.

7. Chetverik, M.S., \& Androshchuk, Ye.V. (2004). Theoriya sdvizheniya massiva gornykh porod $i$ upravleniya deformatsionnymi protsessami pri podzemnoy vyemke uglya. Dnepropetrovsk: RIA "Dnepr-VAL".

8. Chetveryk, M.S., Bubnova, O.A., Babiy, K.V., \& Batur, M.O. (2016) Shvydkist rozvytku deformatsii u pidroblenomu hirskomu masyvi pry vyimanni korysnykh kopalyn na osnovi marksheiderskykh sposterezhen. Heotekhnichna Mekhanika, (130), 3-12.

9. Zberovskiy, V.V., Pazinich, A.V., Polyakov, Yu.E., Potapenko, A.A., \& Angelovskiy, A.A. (2011) Model' predel'nogo sostoyaniya ugol'nogo plasta pri nagnetanii zhidkosti, Zbirnyk Naukovykh Prats Natsionalnoho Hirnychoho Universytetu, (36(1)), 194-199.

10. Zberovskiy, V.V. \& Kostandov, Yu.A. (2011). Predel'noe sostoyanie vybrosoopasnykh ugol'nykh plastov pri ikh gidrorykhlenii s uchetom soprotivlyaemosti uglya sdvigu. Zbirnyk Naukovykh Prats Natsionalnoho Hirnychoho Universytetu, (36 (2)), 36-43.

11. Zberovskiy, V.V., Pazinich, A.B. \& Polyakov, Yu.E. (2010). Otsenka effektivnosti gidroimpul'snogo vozdeystviya po gazovomu faktoru $\mathrm{v}$ zaboyakh podgotovitelnykh vyrabotok. Heotekhnichna Mekhanika, (89), 126-133.

12. Khomenko, O.Ye., Sudakov, A.K., Malanchuk, Z.R., \& Malanchuk, Ye.Z. (2017). Principles of rock pressure energy usage during underground mining of deposits. Naukovyi Visnyk Natsionalnoho Hirnychoho Universytetu, 2(158): 34-43.

13. Kovalevska, I., Barabash, M., \& Snihur, V. (2018). Development of a research methodology and analysis of the stress state of a parting under the joint and downward mining of coal seams. Mining of Mineral Deposits, 12(1), 76-84. https://doi.org/10.15407/mining12.01.076

14. Kovalevs'ka, I., Vivcharenko, V., \& Snigur, V. (2013). Specifics of percarbonic rock mass displacement in longwalls end areas and extraction workings. Annual Scientific-Technical Collection - Mining of Mineral Deposits, 29-33. https://doi.org/10.1201/b16354-7 